\title{
Fascismo italiano na América Latina: entre romanità e latinità
}

Carla Brandalise*

Resumo: $\mathrm{O}$ artigo versa sobre os rumos da política internacional da Itália na época do fascismo, mais especificamente o manifesto interesse que essa nação demostra nos anos de 1920 pela América Latina, julgada naquele momento como factível de uma maior abordagem em termos econômicos e político-culturais. As estratégias de inserção passavam pelos usos políticos da concepção de latinidade, concebida como fator de comunhão entre esses povos. Com tal viés de legitimação, uma série de iniciativas são tomadas pelo regime de Mussolini visando à aproximação com o continente latino-americano.

Palavras-chave. Fascismo. América Latina. Latinidade. Política Internacional.

\section{Introduçáo}

O presente artigo pretende mapear iniciativas emblemáticas da primeira fase do governo Mussolini, nos anos vinte, no sentido de alargar os horizontes de inserção internacional na América Latina. Tratava-se de um ensaio de conquista não bélica ${ }^{1}$ de novos mercados em um espaço considerado ainda em disponibilidade no jogo competitivo entre as potências comerciais da época, bem como de ampliar um prestígio político-cultural julgado na condição de direito histórico. ${ }^{2}$ Tal ambição poderia e deveria ser facilitada pela forte presença de uma comunidade emigrada, no momento em que essa

\footnotetext{
* Professora-Associada do Departamento de História e do PPG em História da Universidade Federal do Rio Grande do Sul - UFRGS. Doutora em História Política pelo Institut dÉtudes Politiques de Paris - Cycle Supérieur dHistoire du 20ème Siècle. E-mail: cbranda@gmail.com.
} 
fosse revalorizada e trazida ao convívio da sua pátria de origem. $\mathrm{Na}$ contraposição, náo seriam trascuradas as autoridades políticas constituídas desses estados latino-americanos, pois, como ambicionava o novo regime, fundamental era a expressáo de uma Itália renovada e disposta a ter real existência em cena mundial. Apesar da, e digno de nota, precocidade da preocupaçáo com o continente latino-americano em relação ao estabelecimento do próprio regime fascista italiano, observa-se o desenho de um certo conjunto de intencionalidades coerentes. Muito dessa antecipação pode ser reportado ao fato de a Itália ter já um histórico de ensaios, em geral teóricos, na América meridional, como em meados do século XIX, com os nacionalistas e colonialistas e suas projeções de uma 'nova Itália' na bacia do Prata. (EINAUDI, 1890; CORRADINI, 1914).

A escolha para a implementação dos propósitos de inserção recaía em dois países latino-americanos centrais, que atuariam como ponta de lança do expansionismo no continente: a Argentina, em especial, e o Brasil. ${ }^{3}$ No decurso, almejava-se avançar em eventuais oportunidades nos demais países, a exemplo do Uruguai, Chile, Peru, Equador e da Venezuela. A estratégia de ação sustentava-se, sobretudo, em dois pilares entrelaçados: o primeiro pilar baseava-se na recuperação discursiva e propagandística de um suposto papel histórico da Itália. Essa última estaria destinada a reassumir seu papel original de líder e paladina da convalescente "raça latina", conforme terminologia da época, promovendo o renascimento da latinità em nome da 'uniâo dos povos latinos' e da proclamação de uma 'cidadania latina universal', em um panlatinismo.

O segundo pilar consistia em uma composição de atitudes, como a fundação em Roma, em fins de 1923, do Istituto Cristoforo Colombo, organismo que, em sua origem, pretendia contar com a presença associada da Espanha e de Portugal e a colaboração dos países latino-americanos. O Instituto deveria, sob liderança da Itália, bem entendido, congregar e irradiar, acima de tudo, a força dos três países europeus para a América Latina, excluindo-se deliberadamente a França, vista nesse momento como uma rival na instrumentalização do conceito de latinità, dado que a mesma reivindicava a primazia na ‘criação' e divulgação da concepção 'latina' em terras americanas ${ }^{4}$. Além disso, também fizeram parte do quadro de empreendimentos, 
alguns desses sob coordenação do Istituto, o envio do príncipe-regente para a América Latina; o despacho da Nave Italia; a construção de cabos telegráficos submarinos; a realização de voos inéditos para a América; a perspectiva de reformulação das representaçôes diplomáticas; a promoção de viagens de comércio e de intercâmbios culturais; o lançamento de uma ampla gama de publicaçóes ou traduçôes voltadas ao melhor conhecimento da América Latina, entre outros. Eis que o continente latino-americano, como era de se esperar, não estava tão isento assim de presença competidora das outras potências, o que faz com a Itália fascista comece a traçar um mapa concorrencial desses considerados antagonistas comerciais, medindo a sua própria competência no campo.

\section{Os anos vinte: a Itália em meio a concorrências e alianças a propósito da latinità e da competitividade comercial}

A Itália, através de toda uma mobilização acadêmica, que resultará em extensa produção textual, manifesta em revistas, livros, panfletos, jornais, boletins etc., 5 reivindica para si a concepção originária do 'povo latino', da 'raça latina'. Passa-se, assim, à defesa do 'direito sagrado e indivisível' da Itália a propósito da latinidade: o Primato. Ora, argumentam os italianos, a latinidade só existe e só mostrou sua força de sobrevivência milenar em função do seu berço e sangue de origem, Roma, a 'grandiosa'. Logo, todos os latinos do mundo seriam, antes, romanos, sendo natural que a líder-mãe da 'raça' fosse a Itália, a representante mais próxima e por direito da civilização romana. A noção de latinità, da qual já haviam se apropriado os 'nacionalistas' italianos, é novamente entendida como um fenômeno de romanità. $\mathrm{O}$ fascismo retoma a metáfora de Roma caput mundi. Inúmeras são as manifestaçóes nessa direção, como a do prefeito de Roma nos anos 1925-1926, Filippo Cremonesi, "Roma vive de vida perene e nós não somos os herdeiros, mas os continuadores da inexaurível força civilizadora. Os latinos da América [...] têm o direito de se considerar romanos, em sua glória do passado, em sua generosa vontade de iniciativas presentes." 6 
Um primeiro passo é dado em direção aos 'italianos partidos ao exterior', onde conjuga-se latinità com romanità e agrega-se italianità, na expectativa de aproximação com sua comunidade espalhada pelo mundo. $\mathrm{O}$ sentido que italianità assumira nessa época é explicitado pelo historiador Emílio Gentile (1986, p. 355, grifos do autor),

[...] o termo italianità foi adotado pelo nacionalismo e pelo fascismo, não apenas para designar a inclusão, através da cidadania, no estado italiano, como também, em uma acepção que pretendia ser politicamente mais acentuada. Ela deveria indicar o sentimento e a consciência de pertencer à nação italiana e exaltar a vontade, em meio aos italianos que viviam fora da Itália, de preservar na sucessão de geraçôes, os vínculos de língua, de cultura, de interesses e de afeição com a nação de origem.

No entanto, a Itália de Mussolini ambicionava algo maior, passos mais retumbantes. Para além da italianità, o novo regime instituído na península lançava-se na reapropriação do conceito de latinità, buscando envolver, assim, não só seus compatriotas de além-mar, e sim, todos os latinos. $\mathrm{O}$ cerne consistia em assumir posição eminente entre as naçóes 'latinas'. Ausonio Franzoni, por exemplo, evoca os caminhos da obra de latinità a ser construída no país argentino, "[...] com seus propósitos, seus meios e suas açóes de propaganda pacífica conduzidas em nome da fraternidade, da cultura e da arte, a Itália e a Argentina fixam as bases eternas da triunfante e incomparável civilização latina." 7

Assim, nesses anos de 1920, intençôes e diretivas voltadas à América Latina são progressivamente idealizadas e implementadas pelo regime fascista italiano e seus colaboradores, obedecendo, porém, uma colossal distância entre o projetado e o realmente realizado. Dessas proposiçóes, algumas eventualmente obtiveram resultados positivos, sobretudo se comparadas às parcas açóes dos governos italianos anteriores. No frescor do regime, tudo parecia possível. Tratava-se antes de uma questão de espírito empreendedor, de perseverança, visando a recuperar os atrasos históricos, através da adoção de meios performáticos. 
Para a lógica fascista, a latinità do subcontinente estampava-se como um fato dado e irreversível, devendo naturalmente ser percorrida e explorada, a fim de desvendar o que essa identidade comum continha como critério de comunhão. Segue-se entáo a consideração de que, na América Latina, seria preciso avançar mediante informaçóes mais exatas; construir sobre bases mais racionais. A disposição em melhor conhecer o subcontinente veiculando pesquisas antes de agir se impóe. Julga-se necessário dispor de esclarecimentos cartográficos, de análises das estruturas de poderes locais, de uma compreensão aprofundada da vida econômica, de subsídios dos meandros culturais. O escritor Mario Puccini, como um admirador e propagandista da cultura hispânica, pronunciara-se sobre o "[...] necessário esforço de espírito que se deve realizar para reencontrar a América Latina”:

Não se pode dizer que a Itália de hoje é aquela de vinte anos atrás, toda recolhida em si mesmo e pouco atenta aos problemas espirituais e sociológicos de outras naçóes da Europa e do mundo. A Itália de hoje é mais bem informada do que se passa no exterior, sobretudo no domínio político. Mas existe ainda algumas lacunas, das quais uma é verdadeiramente detestável [...]: a falta de conhecimentos renovados sobre as repúblicas americanas de língua espanhola [...] de sua evolução e seu desenvolvimento histórico, povos destinados a açóes superiores. ${ }^{8}$

O impulso vem, em especial, do Estado, o qual espera intervir para eliminar o torpor e estimular os empreendimentos. E, para direcionar uma obra tão ambiciosa, o governo planeja uma intervenção estatal eficiente. As formulações políticas e a gestão adequada dos meios materiais alocados deveriam, assim, ser enquadradas pela administração central do Estado, com o apoio de um espectro empresarial supostamente ativo e de um meio intelectual e artístico condizente à missão. A Península quer submeter seus possíveis recursos disponíveis às virtudes da regulamentação, que corrigiria os defeitos e as naturais tendências dispersivas. ${ }^{?}$

Em termos práticos, a Itália sob o fascismo pensa igualmente em oportunizar a aproximação política que vinha sendo anunciada 
com a recente ditadura espanhola do general Miguel Primo de Rivera. Ao levar em consideração a posição, julgada privilegiada, que a Espanha deveria dispor junto às naçóes americanas de língua hispânica, o Duce intencionava promover acordos hispanos-italianos destinados a fazer progredir a influência política e econômica da Itália no ultramar. ${ }^{10} \mathrm{~A}$ proposta de acordo estender-se-ia também a Portugal e, em seguida, ao Brasil, a fim de criar uma 'união cultural latina', sob a justificativa de que

[...] a importância dos valores espirituais comuns entre os países latinos precede e ao mesmo tempo avaliza todas as formas sucessivas de relaçóes. E a figura espiritual que liga essencialmente o mundo Ibérico à Itália é aquela de Cristóvão Colombo. A Espanha lhe acordou a confiança e os meios de conduzir sua façanha. $\mathrm{O}$ ato de nascimento da América nos mostra que a Itália e a Espanha, entrelaçadas, sustentaram o novo continente na sua fonte de batismo. ${ }^{11}$

A conclusão de pactos de amizade e de tratados de comércio entre a Espanha e a Itália abriria "[...] uma colaboração no vasto campo de interesses que os dois Estados dividem no que diz respeito às repúblicas sul-americanas [...] permitindo à Itália se aproximar mais intimamente da Espanha e fazendo que a ação dos dois povos se torne fecunda em resultados." ${ }^{12}$ A Espanha demostrou a princípio boa vontade. Rivera almeja dar a seu país um peso suplementar na cena internacional. Por ocasiáo de uma visita a Roma, em novembro de 1923, o general espanhol declara, rememorando sua própria tomada de poder, que o exemplo de Mussolini "foi a preparaçáo do ambiente, a eletrificação da atmosfera", e ele acrescenta que o Duce "[...] permanece sempre o guia da Espanha na via da reconstrução, do progresso e da ordem.” (apud MILZA, 1991. p. 248). No entanto, em relação aos países hispano-americanos, a Espanha prefere manter certa prudência, julgando ter in lócus acessos privilegiados aos quais não necessariamente pretendia compartilhar (MÉNDEZ, 2013a, p. 16).

Um dos acontecimentos vindos para agregar as 'naçóes latinas' constituiu-se na fundação de um centro de estudos, investigação e irradiação da 'panlatinidade', o Istituto Cristoforo Colombo, com 
sede na Via Cavour. O novo instituto refletiria, assim, os ensaios convergentes não só com a Espanha, mas também com Portugal e países latino-americanos o sentido de superação de eventuais divergências. $\mathrm{O}$ professor Luigi $\mathrm{Bacci}^{13}$, um dos principais idealizadores do Istituto, expóe o caráter e os propósitos do mesmo:

Sua fundação constitui um dever de italianità; ele irá encorajar uma cooperação eficaz para que a civilização latina não seja considerada como uma simples expressão de retórica; antes, seja percebida como uma grande força de expansão, colocada a serviço dos interesses que a Itália já possui e pretende desenvolver com mais vigor com a Espanha, Portugal e, mais particularmente, com os países latino-americanos. Entre a Itália, a Península Ibérica e estes povos longínquos que pertencem à nossa raça, é preciso novas e mais sólidas amarras. Entre a Itália e todos esses países, não subsiste nenhum desacordo, não existe e nem pode existir nenhuma desconfiança. ${ }^{14}$

O Istituto quer ser um estabelecimento voltado à difusão de um "[...] programa orgânico, síntese do pensamento dos países diretamente concernidos, quer dizer, a Itália, a Espanha, Portugal e as naçóes latino-americanas." ${ }^{15}$ Espanha e Portugal fazem-se representar através de seus membros diplomáticos creditados junto à corte do rei da Itália. Circulares são despachadas aos países latino-americanos (LERMA, 1989, p. 276). A efetiva participação dos parceiros Ibéricos e das naçóes da América Latina na nova organização, porém, irá se revelar fraca ou falaciosa, seja por falta de interesse ou de recursos, seja porque a nação italiana assume a dianteira. É a Itália que dará sentido e interpretação ao Instituto. ${ }^{16}$

A Itália, a madre di tutta gente latina, quer praticar uma ativa propaganda intelectual, artística, científica e econômica personalizada através do Instituto. Importantes personagens do regime estarão presentes. O Presidente honorário será Benedito Mussolini; seu vice-presidente, Giorgio Guglielmi De Vulci. Como presidente do Conselho Deliberativo, Amadeo Gianini; sendo secretário geral, Luigi Bacci. Entre os 43 conselheiros, encontravam Giuseppe Botai, Giuseppe De Michelis, Giorgio Del Vecchio, Giovanni Giuriati, Ciro Trabalza. ${ }^{17}$ 
Segundo sua normatização, o Instituto não seria uma organização de caráter puramente público, na medida em que interagiria com o setor privado. Da mesma forma, promoveria a colaboração entre os estados associados, as coletividades emigradas desses últimos e indivíduos diretamente interessados. As disposiçóes estatutárias pormenorizavam os interesses de cada país-membro. No que dizia respeito à Itália, essa deveria, entre outras execuçóes,

[...] desenvolver pesquisas e implementar todas as iniciativas diretas a fim de estabelecer as mais amplas relaçóes econômicas entre a Itália e os países latino-americanos; promover a constituição e a fomentação de organismos e sociedades que tenham por objetivo favorecer e expandir as trocas comerciais entre a Itália e esses países latino-americanos. ${ }^{18}$

O que acontece de fato é que a Itália acaba por oferecer a sede social, formula os principais projetos e fornece praticamente todo o capital. A potencialidade da Espanha no continente além-mar logo é colocada em dúvida, como observa-se no relato do adido comercial no Chile, Tommaso Mancini (1924, p. 14). Ele adverte sobre a inutilidade e os malefícios que representaria supervalorizar a influência do país espanhol na América hispânica,

[...] o pior de tudo seria a ilusão que o avizinhamento ítalo-espanhol possa nos dissuadir de colocar em obra nossa própria propaganda na América, sendo essa propaganda uma necessidade maior. $\mathrm{O}$ erro seria acreditar que a aproximaçáo por ela mesma tornaria para nós o ambiente mais propício [...] A Espanha náo pode repousar na certeza de dispor de um domínio que, se um dia existiu, é hoje em dia asperamente disputado por outros povos, não em virtude do sangue ou de um passado comum, mas por habilidades expansionistas; estes povos concorrentes esquadrinham o terreno e triunfam sobre os países mais fracos e ingênuos.

Quanto a Portugal, sua participação se faz de tempos em tempos, estando em meio a graves adversidades econômicas, com o Tesouro à 
beira da falência e prejudicada pelo escasso valor de mercado de seus produtos agrícolas. Além disso, o país português encontra-se internamente em convulsão devida às agitaçóes operárias e aos problemas políticos, acontecimentos que levarão finalmente ao putsch militar de maio de 1926, conduzido pelo general Gomes da Costa (MILZA, 1991, p. 250). Portugal náo conseguirá manter mais do que um frágil vínculo com o Instituto. Os países latino-americanos, de sua parte, exerceráo em geral o papel de receptores das iniciativas ítalo-espanholas. A Argentina será a mais presente. De qualquer forma, o governo Rivera, frente às dificuldades militares no Marrocos e às agitaçôes separatistas da Catalunha, não terá a impulsão necessária para restabelecer ou aumentar sua influência na América hispânica, nem poderá se aventurar na possível construção de uma política comum com a Itália. Concedendo um esforço mínimo de participação, a Espanha segue o impulso italiano, esperando obter algum benefício (LERMA, 1989).

$\mathrm{Na}$ prática, o novo Istituto pretendeu reunir todo o gênero de informações sobre os países latino-americanos; promoveu viagens de negócios, missóes de investigação e de estudos. Estabeleceu concursos e premiaçóes a trabalhos referentes ao subcontinente; financiou a permuta de professores, alunos, pesquisadores e artistas. Numerosas obras são publicadas ou traduzidas, como monografias ilustradas, de caráter geopolítico, cultural e econômico, sobre as naçôes latino-americanas. ${ }^{19} \mathrm{~A}$ mais visível publicação do Istituto é a revista bimestral denominada Colombo, fundada em 1926, que apareceu até 1930. Dirigida por Luigi Bacci e redigida em italiano, espanhol e português, o periódico apresenta-se como "a revista dos fatos italianos e latino-americanos". Nela figuravam artigos de nomes destacados do mundo literário, artístico, científico e político do momento, a exemplo do escritor Arturo Farinelli, membro da Reale Accademia d'Italia; do ex-presidente do Conselho, Vittorio Emanuele Orlando, o qual havia percorrido a Argentina e o Brasil no imediato pós-Primeira Guerra; do filósofo Giovanni Gentile; do historiador Gioacchino Volpe; do jornalista e escritor Luigi Federzoni. ${ }^{20}$

A revista Colombo pretendia igualmente "[...] ser o órgão de conexão entre as jovens naçôes da América Latina, a Espanha, Portugal e a grande Madre Italia", e tinha por objetivo promover a divulgação, até a mais longínqua região do Novo Mundo, "do progresso que a 
Itália realiza em cada setor da atividade humana." ${ }^{21}$ Benito Mussolini escreve o prefácio do primeiro número de Colombo, anunciando o caráter e as perspectivas da revista:

Eu estou satisfeito de agregar meu nome à primeira página dessa revista que o Istituto Cristoforo Colombo - do qual eu sou o presidente honorário - consagra ao estudo dos povos ibero-latino-americanos, para reafirmar, graças a um mais profundo conhecimento mútuo, suas relaçóes com a Itália. Desde que eu assumi o governo da Itália, eu enviei mensagens aos italianos que vivem na América e aos países que lhes acolhem. Após quatro anos, minhas esperanças não mudaram. As relações envolvendo a Itália e os povos ibéricos e latino-americanos são fecundadas cotidianamente pela fé e pelo trabalho tenaz desses italianos partidos para a América Latina. ${ }^{22}$

Paralelamente às suas atividades editoriais, o Instituto buscava organizar comitês representando cada país associado. Tais comitês promoveriam relaçóes recíprocas e, entre outras tarefas, deveriam fundar e/ou dinamizar as 'Câmaras de Comércio e Indústria'. Em 1926 é criado o Comitê ítalo-brasileiro, do qual participam as autoridades diplomáticas brasileiras presentes na Itália e outras personalidades que testemunham a respeito do Brasil, interesses variados. Nos mesmos moldes, o Comitê ítalo-peruano e o Comitê ítalo-boliviano foram estabelecidos logo em seguida. Porém, já em fins da década de 1920, as funçóes do Istituto passam a sofrer forte concorrência dos Institutos Italianos de Cultura fundados no exterior.

\section{Glória à Nação: desembarques notáveis na América Latina}

$\mathrm{Na}$ esteira da Espanha ${ }^{23}$, a Itália envia seu príncipe-herdeiro, Humberto de Saboia ao subcontinente em meados de 1924. A intenção da visita aparece no relato de Amadasi, publicado na revista $L e$ Vie d'Italia e dell'America Latina: 
[...] vejam no filho do Rei, toda uma Pátria que se desloca além-mar, orientando seu olhar em direção ao reconhecimento e à admiração que merecem a energia e a fidelidade já provada de todos os seus filhos. Eis o filho do rei que passa de uma borda a outra para afirmar a superbíssima potência atual da Itália, e permutar gestos e vínculos de amor com seus distantes súditos. ${ }^{24}$

O cruzeiro que transporta o príncipe passa em primeiro lugar por Buenos Aires, onde é recebido pelo presidente da República, Marcello de Alvear. A visita estende-se em um circuito de quinze dias pelo interior do país, nas principais comunidades de emigraçáo italiana, como La Plata, Rosário, Tucumán, Córdoba, Mendonza. O tom apologético aparece no relato de Amadasi, "[...] os irmáos italianos sentiram renascer e retumbar o sentimento d'italianità, e eles foram assegurados da uniáo que a Patria quer manter com seus filhos." ${ }^{25} \mathrm{O}$ príncipe segue para o Chile e Uruguai. A parada no Brasil fora cancelada devido a distúrbios internos em que o país vivia no momento. Teria sido desaconselhada pelo próprio governo brasileiro. ${ }^{26}$

A imprensa da América meridional ecoa essa visita considerada prestigiosa. A revista Plus Ultra da capital argentina, por exemplo, publica uma edição extra consagrada à estadia de Humberto de Saboia, "[...] a vinda do príncipe nos ofereceu a ocasiáo de demonstrar ao ilustre representante do povo, do governo e da família real da Itália, nossa firme simpatia, fruto natural do profundo vínculo de sangue, de cultura e dos interesses que unem os italianos e os argentinos". ${ }^{27} \mathrm{O}$ Jornal do Brasil, por sua vez, observa em relação à viagem do príncipe: "A Itália, em sua incomparável confiança nos destinos da latinità, não economiza seus esforços para dar um novo vigor à solidariedade entre todos os povos ligados à matriz latina." ${ }^{28}$

De forma quase concomitante, envia-se à América Latina pela primeira vez uma 'feira-exposiçáa' flutuante, a Esposizione Campionaria dell'industria e dell'artigianato italiani: mostra Itinerante della Crociera Commerciale nell'America Latina, a bordo da Nave Italia, entre fevereiro e outubro de 1924 . O escopo da missão passava pela promoção mercantil, pela prospecção da ampliação de mercados e agilização de contratos comerciais, como também pela ampla difusão 
da cultura italiana e pelo reforço dos laços com a comunidade italiana emigrada. ${ }^{29} \mathrm{O}$ alcance dessa empreitada foi observado pelo historiador Emilio Gentile (1986, p. 379, grifos nossos):

Desde os primeiros tempos que se seguiram a sua conquista do poder, o fascismo manifestou um interesse especial pela Argentina [...] Mas, a primeira aproximação importante e direta do problema de emigraçáo e da italianità na Argentina teve lugar durante o cruzeiro da Nave Italia na América do Sul.

A 'feira-flutuante' resultara de uma ação conjugada entre o governo fascista e os setores industriais e comerciais italianas, em meio a articulaçóes com as autoridades dos países latino-americanos. Portava como metas,

[...] demonstrar às populações da América Latina a precisa sensaçáo da potencialidade e da renovada vontade de açáo que anima o nosso país; e confirmar aos nossos concidadãos, que vivem e trabalham na América Latina, o legítimo orgulho de sentirem-se filhos desta terra, ilustre entre todas ao longo dos séculos pela sua excelência. ${ }^{30}$

Tratava-se, assim, de "[...] demonstrar o que a Itália sabe e pode produzir e aproximar os produtores italianos dos grandes centros de consumo da América Latina, para que eles conheçam as exigências e as necessidades deste mercado."31 Tais exposiçóes de produtos eram uma prática frequente na Europa, mas a julgar pela declaraçáo do entáo nomeado, para esta missáo, embaixador extraordinário da Itália junto aos países latino-americanos, Giovanni Giuriati ${ }^{32}$, àquela reservada para a América Latina revestira um caráter particular, "[...] a Nave foi o maior e o mais límpido dos gestos de fraternidade latina realizado pelo governo fascista. Benito Mussolini nos esclareceu sobre a necessidade de frisar a tarefa mercantil e espiritual da Nave Italia. ${ }^{\prime 33}$

A exposição contava igualmente com uma forte missão de cunho cultural, cuja intencionalidade é narrada pelo integrante da Nave e responsável artístico da missão, o artista visual Giulio Aristide Sartorio. ${ }^{34}$ Em suas observaçôes, chamava a atençáo, mais uma vez, 
do ostracismo da 'presença da Itália' na América Latina, mas considerava ser possível, em tempos de governo fascista, remediar tal situação desconfortável:

\begin{abstract}
Nós enfim compreendemos que a arte italiana possui a capacidade e está em condiçôes de ser um elemento de integração por excelência. Infelizmente, em toda a América Latina, a arte italiana, como a nossa emigração, aliás, está abandonada a si mesma. Hoje, quando as condiçôes são, na Itália, moralmente diferentes, nós não podemos renunciar à nossa expansão intelectual..$^{35}$
\end{abstract}

O planejamento geral da Nave, por sua vez, fora realizado pelo poeta ligado ao regime, Gabriele D’Annunzio. Dividia-se em dezessete salas, contando, entre outras, com seçóes de livros, arte popular, pequenas indústrias regionais, indústrias de armamento, de seda, de cerâmicas, de produtos agrícolas, minerais etc. Participaram 567 empresas, com uma tripulação de cerca de setecentas pessoas, compondo empresários, jornalistas, autoridades políticas, artistas, intelectuais. A visita desenrolou-se ao longo de treze países, em suas principais cidades portuárias; no Brasil, nos estados de Pará, Pernambuco, Bahia, Rio de Janeiro, Sáo Paulo, Rio Grande do Sul. ${ }^{36}$ No Uruguai, Montevidéu. Na Argentina, Buenos Aires, Bahia Blanca; no Chile, Valparaíso. ${ }^{37}$ A todos, Benito Mussolini envia uma mensagem oficial,

[...] a extensão do imenso território americano nos oferece uma
via através da qual os povos modernos podem se conhecer
e se estimar no domínio do trabalho. Nós desejamos que
esta fecunda fraternidade persevere e se torne sempre mais
ampla e mais íntima pelo interesse mútuo, material e moral,
da Itália e dos países latino-americanos. ${ }^{38}$

No entanto, a despeito desse esforço, Giovanni Giuriati (1925) apresenta a Mussolini conclusôes não tão otimistas acerca da viagem. O embaixador extraordinário da Nave Italia tinha uma missáo complementar. Tratava-se de observar e relatar o grau de afinidade e engajamento à Madre Patria das comunidades italianas residentes nas 
Repúblicas visitadas. Em suas impressões, Giuriati dimensiona que o sentimento de italianità ainda seria forte, confiável e recuperável apenas em algumas pequenas colônias no interior das províncias, mas em comunidades urbanas em grandes cidades, como São Paulo e Buenos Aires, encontrava-se antes a dispersão, a desestruturação e a desconfiança. Nos grandes centros, todo trabalho de aproximação seria mais difícil, sobretudo na Argentina.

Recomendava, ainda, adequaçáo nos propósitos do novo regime em tomar a comunidade emigrada como "método de expansão política e econômica” no continente (GIURIATI, 1925, p. 11). Para preservar a italianità, seria preciso colocar em questáo o Commissariato per l'emigrazione, através da introdução de informações e estimativas mais consistentes e de planificaçóes políticas concernentes aos países dos quais dependiam esses emigrados italianos. A Argentina, exemplificava o Ministro, possuía um meio ambiente tão propício à assimilação e à perda de sentimentos em relação à pátria de origem que logo os italianos esqueciam de seu passado. Giuriati confirmava, dessa forma, a necessidade da existência de um Instituto como o Cristoforo Colombo, engajado justamente nesta sistematização analítica do continente.

Por sua vez, o jornalista e escritor italiano Pietro Belli (1925, p. 25), também participante da Nave, analisara as condiçóes de vida dos emigrados italianos, no Brasil em particular. Com um tom de indignação, em seu relato, Belli solicita a intervenção de seu governo quanto às condiçóes desumanas dos italianos nesse país:

Eu vi fábricas onde os operários são tratados como animais; eu vi jovens vivendo de maneira desumanizada, eu vi mulheres precocemente envelhecidas pela poeira asfixiante de lojas exposta a tudo, ao vento, a chuva; na Itália, o operário é um senhor mesmo quando ele ganha pouco, porque na Itália, ele vive e trabalha por todos os lugares em condiçóes de civilidade.

A Nave é, no entanto, o anuncio de várias missóes comerciais e culturais enviadas posteriormente pela Itália à América Latina e vice-versa, a exemplo do grupo de Miláo vindo ao Brasil no começo de 1925, sob os auspícios do 'Instituto fascista de propaganda nacional', 
com vistas a prospecçóes no campo dos negócios. Já na Itália, durante e após o circuito marítimo, ocorre todo um esforço publicitário e propagandístico para divulgá-lo através de jornais, livros, informes, relatórios, emissão de selos temáticos. Igualmente são realizadas projeçóes cinematográficas ao grande público, com a estreia da programação prestigiada com a presença do Rei, do Primeiro Ministro e do corpo diplomático latino-americano creditado junto ao Quirinal. ${ }^{39}$

\section{Os obstáculos: a concorrência econômica e político-cultural na América Latina}

Apesar de a Itália sob o fascismo ter avaliado, nesses anos de 1920, que poderia avançar no continente latino-americano, a realidade da região mostrava-se muito mais difícil, em meio a uma variedade de problemas, entre eles a própria competição entre as potências na consolidação de seus interesses. Nesta atmosfera, a Península constrói, em termos de disputa pelo espaço comercial e político-cultural na América Latina, um quadro de 'émulos concorrenciais', os quais, de alguma maneira e na medida do possível, devia-se tentar investigar, talvez suplantar ou igualar. Entre eles, despontava a rivalidade com a França, a quem o governo fascista considerava quase como uma questão de honra medir forças, em especial no domínio da cultura. Há também a Alemanha, para a qual não deixava de esboçar certa admiração pela eficiência. Ainda observava-se, ao fundo, o avanço implacável dos $\mathrm{EUA}^{40}$ e a incontestável presença da Inglaterra em termos econômicos. Assim, nesse território, era preciso “[...] enfrentar os países cujos trabalhos não são menos densos, nem menos intensas a propaganda dispendida para difundir os seus valores. ${ }^{\prime 11}$

Ao comparar as conquistas anteriores de determinados países europeus na América Latina, em especial, a França, com sua própria falta de desenvoltura no passado, a Itália fascista vai responsabilizar severamente o fraco senso de oportunidade dos governos liberais italianos precedentes. A despeito das vantagens que a Península transalpina possuiria, sobretudo, na porção sul da América Latina, como sua forte comunidade étnica, os governos anteriores teriam 
permitido, sem quase opor resistências, que a nação francesa se impusesse como modelo cultural por excelência no continente. Tais governos liberais seriam então responsáveis por ter deixado nascer, em meio aos latino-americanos, uma tradição de receptividade ao magistério moral da França e não da Itália.

Avalia-se, “[...] os franceses nos fazem concorrência há anos nesse imenso território". Critica-se mesmo pequenas iniciativas pontuais da nação europeia vizinha. Segundo a revista Colombo, a França promovia inserçóes culturais constantes nesses lócus, a exemplo da ingerência na direção do maior teatro da América Latina, o Teatro Colón, em Buenos Aires, substituindo a presença italiana. E ainda, a proposta de criação de um teatro d'avant guarde, encenando permanentemente obras francesas, o que constituiria "[...] um novo ataque frontal contra a nossa cultura, e isto mereceria a devida atenção de nosso governo." ${ }^{2}$

A França, de fato, pretendeu nesses anos vinte retomar seus investimentos e sua presença na América Latina, abalados por ocasião da Grande Guerra de 1914. Em 1925, assiste-se, entre muitos outros empreendimentos nesse sentido ${ }^{43}$, à fundação na capital francês da Association Paris et Amérique latine. Na Itália, o gesto náo passa despercebido. Com ironia e desconfiança, a revista do Istituto Cristoforo Colombo revela suas impressóes, dando a entender que se tratava quase de um plágio de seus propósitos.

Tanto seu estatuto social quanto os objetivos dessa nova associação francesa, se substituíssemos o nome da França pelo da Itália, reencontraríamos os mesmos preceitos e as mesmas intençóes que, desde sua fundação, se propôs e se propóe o Istituto Cristoforo Colombo: desenvolver uma propaganda intelectual, artística, científica e econômica ativa e recíproca na América Latina [...] nosso exemplo teve influência e discípulos eficazes no além-Alpes. ${ }^{44}$

A Association Paris et Amérique latine, também chamada de Cercle Paris-Amérique Latine, sediava-se no Boulevard de la Madeleine e funcionou da data de sua fundação até 1930. Entre suas iniciativas estavam a promoção de congressos, exposiçóes, conferências, concertos musicais, bem como o incentivo às trocas acadêmicas 
universitárias e demais recursos para destacar a cultura francesa no continente latino-americano e vice-versa. Compunha-se igualmente de conhecimentos e dinâmicas comerciais. ${ }^{45}$

Logo, mais uma polêmica forma-se entre os dois países, quando o periódico francês, La Revue de l'Amérique latine, publica, em fins de 1926, uma série de observaçóes sobre os italianos emigrados à Argentina e ao Brasil. Afirma-se que os anos de fluxo migratório dos italianos em direção à América Latina correspondiam àqueles em que se procurava escapar do serviço militar e às guerras da Abissínia, de Trípoli etc. Em seguida, é relatado a rápida assimilação dos italianos emigrados e sua falta de patriotismo. Segundo o periódico francês, esses mesmos italianos de além-mar não aportavam o apoio necessário de que a Itália necessitaria para dinamizar suas relaçóes comerciais. Pelo contrário, várias exploraçôes agrícolas e industriais haviam sido criadas por esses emigrados, o que inviabilizava ainda mais as possibilidades de exportação do Reino da Itália. E o periódico completa, "[...] o pequeno número de italianos que possuem uma posição social elevada não são recebidos em sociedade, enquanto os franceses o são." ${ }^{\prime 6}$ Como era de se esperar, essas declarações são severamente rechaçadas e consideradas uma provocação pelos italianos. ${ }^{47}$

O escritor e político argentino Manuel Ugarte, colaborador da revista Colombo, reforça o mal-estar dos italianos, ao reclamar da falta de atitude desses em se valorizar como difusores de cultura na América Latina, na contraposição não só aos norte-americanos, mas aos franceses.

Por que não ocorre ao espírito da juventude latino-americana vir à Itália beber diretamente da fonte da latinità? Fala-se sempre das relaçóes comerciais, da emigração numerosa, mas se esquece do fluxo ao Novo Mundo das ideias, das artes, da civilização desta extraordinária Itália. Por que razão a Itália, superior em sua irradiação universal, não vê na América Latina um campo aberto à ação de seus filhos? Por que ela não estende ao outro lado do Oceano, o tesouro inesgotável de seu gênio? 48

Por sua vez, em relação à Alemanha e sua política pangermanista 'além-Atlântico', a Itália fascista parecia nutrir uma inequívoca 
admiração, bem como uma desconfiança intrínseca. ${ }^{49}$ Tal política pangermanista, que vinha sendo desenvolvida pela Alemanha desde fins do século XIX, sofrera ampla desestruturaçáo com a Primeira Guerra Mundial. Porém, em meados dos anos de 1920, o governo alemão, mesmo em sua grave crise interna, já buscava reestruturar suas relaçóes comerciais internacionais, incluída a América Latina. Daí a percepção italiana.

O país germânico é visto como um notável adversário comercial, pois atuaria nas mesmas faixas que a Itália tinha pretensão, e isso mesmo sendo, como a península italiana, uma nação de formação recente, frisa Tommaso Mancini (1925, p. 14). Para esse último, ao falar sobre os benefícios de uma política de propaganda mais eficaz no estrangeiro por parte da Itália, a Alemanha raiava como um ponto de referência:

A propaganda cultural precede sempre, na ordem do tempo, a qualquer tipo de iniciativa. A Alemanha, que foi certamente a mais hábil conquistadora dos mercados sul-americanos, utilizou, como porta-estandarte de sua expansão econômica, legióes de professores e avalanches de livros. É nesse exemplo que nós devíamos nos espelhar em particular, considerando que, sob vários aspectos, nossa situação naturalmente pode se aproximar daquela do Império alemão, tanto do ponto de vista demográfico, quanto do ponto de vista capitalista.

Mancini (1925, p. 15-16) sintetiza o que considera as causas da sagacidade alemá, do seu sucesso em conquistar os mercados, nem todas açóes necessariamente legais, mas longe da ineficiência italiana no ramo. Tratava-se da ampla conjugação de interesses entre o governo e as companhias de navegação hanseáticas; das virtudes do sistema alemão de crédito a longo prazo; da habilidade em 'falsificar' marcas; do uso de dumping; da adaptação das mercadorias aos gostos da clientela e aos costumes locais; da formulaçáo de propagandas de acordo com as regióes de inserção; das competências nas embalagens, transporte e entrega de produtos.

Nesses mesmos quesitos, advertências mais extensivas dirigiamse à falta de aptidão italiana em sua tentativa de inserção comercial sul-americana. Repreende-se a não renovação ou formulação de 
tratados bilaterais comercias; a inadequação dos tratados já existentes; os preços elevados não concorrenciais praticados; a grave falta de pessoal capacitado e a imperícia dos intermediários; a ausência de iniciativas congruentes; o desconhecimento dos mercados; a indiferença dos serviços marítimos; e, sobretudo, a impropriedade dos serviços consulares. Alfredo Cusano (1920, p. 30-31, grifos do autor), por exemplo, manifestara-se sobre a fraqueza dos meios de transporte comerciais italianos, referindo-se aos ingleses e aos alemáes:

The trade follow the flag, os ingleses são uma fonte de ensinamento. Precisamente eles que dominaram o comércio internacional graças às suas numerosas linhas de navegaçáo. E, se essa verdade econômica inconteste enriqueceu o comércio britânico, seguida de perto pelo comércio alemão, por que a Itália, que tem justamente nos países sul-americanos tantos interesses e tantos filhos, desdenhou o transporte marítimo?

Com efeito, a Alemanha, da mesma forma que a Itália, visualizara, há tempos, a potencialidade da sul-América, onde, justamente essa propalada ampla ineficiência 'latina', poderia ser um bom indício para uma maior interposição. ${ }^{50} \mathrm{O}$ relato do pangermanista Wilhelm Vallentim, de 1908, mostra-se elucidativo na supervalorização da presença alemã e nos seus julgamentos da inferioridade 'latina':

Reconheçamos que, no continente sul-americano, eles [alemães] exercerão uma influência significativa na construção do futuro da regiáo. A raça latina, até aqui, demonstrou um gênio criador e cultural muito limitado. É evidente que tudo o que se realizou de importante aconteceu em zonas povoadas por alemães, em locais onde eles puderam exercer com certa liberdade sua influência benéfica. ${ }^{51}$

Numerosos institutos germânicos haviam surgido no continente latino-americano, entre 1880 e 1914, voltados em especial para promoção da expansão econômica alemã, mas também para dar visibilidade à sua cultura, cuja Associaçâo para o Germanismo no 
Estrangeiro (Alldeutscher Verbant) era uma das protagonistas. (BIDWELL, 1939). Profundamente abalada pela Grande Guerra de 1914 e após pelas suas reparaçôes, momentos em que seus negócios na América Latina sofreram um forte recuo, a Alemanha não renunciara à sua presença no continente. A reaparição do capital alemão far-se-á com determinação sobretudo a partir de 1926, mas sem ser comparável às posiçôes perdidas em 1914. Assim, às vésperas da crise de 1929, a Alemanha tinha algo em torno de duzentos milhóes de dólares investidos na América Latina, quando o Império alemão de Guilherme II possuía cerca de 850 milhóes.

\section{Itália e América Latina: operacionalidade do contato}

$\mathrm{Na}$ expectativa de ampliar as dinâmicas de aproximação, de intervenção, de propaganda e difusão da imagem positiva e produtiva da 'nova Itália' concretizam-se alguns projetos. Além da tentativa considerada urgente e prioritária de reformular a precária rede de embaixadas e consulados presentes no subcontinente, com o envio de diplomatas 'engajados' na política do novo regime ${ }^{52}$, um evento de envergadura foi a construção de um cabo telegráfico submarino através do Atlântico pela empresa Italcable. Objetivava-se aqui garantir espaço na chamada 'guerra de informaçáo'. No domínio da transmissão e da circulação geral de notícias, os italianos consideravam-se seriamente prejudicados por causa da sua "dependência absoluta em relação às companhias estrangeiras" ${ }^{53}$ Essas últimas monopolizariam as comunicações europeias com as Américas, promovendo uma verdadeira "guerra de palavras" ao obter ganhos político-morais e vantagens concorrenciais, pois dispunham da primazia em dados econômicos, a exemplo das cotaçóes de grãos, de algodão e de metais latino-americanos. ${ }^{54}$ Essa sujeição a memorandos capitais obtidas de segunda mão e talvez nem sempre verídicas, desconfiavam os italianos, não era condizente com o 'novo papel' da Itália.

Cabogramas atrasados, nem sempre legíveis, teriam feito a Itália perder importantes negócios nas Américas, face a competidores melhor esclarecidos. Tal ressentimento recaía, em especial, sobre a Inglaterra, que ocupava uma posição proeminente dado que possuía mais da 
metade do total de cabos do mundo, mas também se projetava sobre a França e os Estados Unidos, detentoras igualmente de cabos. Através da Inglaterra chegava a parte substancial das notícias europeias à América, mas também os informes vindos da África, Ásia e Austrália. No que se dizia respeito às informaçóes sobre a Itália, acusava a imprensa italiana, as notícias transmitidas eram as piores possíveis, deformadas para macular o país. Enfatizavam roubos, violências, extorsóes etc. ${ }^{55}$

A Itália dispunha de apenas 1,07\% da rede mundial de cabos, sem contar com nenhuma ligação direta com suas colônias de emigração, algo considerado de grande gravidade para a promoção de seu nome em termos internacionais. Em março de 1925, a nação italiana inaugura seu cabo telegráfico submarino ao longo do Atlântico ligando seu território aos Estados Unidos. O feito é definido por Mussolini como "[...] um braço gigantesco estendido da Pátria a seus filhos." 56 Em outubro de 1925, tem-se a ligação por cabo 'AnzioBuenos Aires', passando por Málaga, Las Palmas, San Vincenzo, Fernando de Noronha, Rio de Janeiro, Montevidéu. Unia assim Itália, Espanha, Portugal, Brasil, Uruguai e Argentina ${ }^{57}$. Comemora-se "[...] a conexão tão extensa de vários milhóes de italianos, residentes na América do Sul, à Madre Patria. A voz direta italiana é daqui para frente uma realidade." 58 Sobre os benefícios que a nova via de comunicação poderia trazer à relação entre o Brasil e a Itália, bem como a contribuição brasileira à realização da mesma, o italiano, estudioso do corporativismo, Luigi Incisa (1926, p. 227) escreve nas páginas de seu relato de viagem, Nel Paese della Fazenda:

[...] para chegar a uma inteligente, ativa e produtiva colaboração deve ser superada não somente a imensidão do Oceano, mas também o fosso de preconceitos que separam os dois países. Por esta razão, o estabelecimento dos cabos submarinos italianos é motivo de grande comemoração. Os cabos, graças a um significativo aporte financeiro brasileiro, repousam há alguns dias no Atlântico, ligando os dois países com a força do aço. Essa proeza representa o começo de uma nova era de potente cooperaçáo ítalo-brasileira, na via do progresso e da civilização. 
Em outro domínio, voltado às proezas industriais na área da aviação do regime, promove-se, em 1927, o voo inédito do coronel Francesco De Pinedo, no aparelho denominado Santa Maria. O percurso empreendeu três etapas centrais: Itália-Buenos Aires; Buenos Aires-Nova York; Nova York-Itália. No caminho, vários outros países foram visitados, entre eles, o Brasil e o Uruguai. Em entrevista acordada ao jornal argentino Patria degli Italiani, Pinedo expóe o objetivo de sua viagem: "Nós queremos demonstrar ao mundo inteiro que a indústria italiana em geral, e aquela da aviação em particular, chegou a um tal grau de perfeição que ela não teme mais a concorrência. Todos as peças que compóe o Santa Maria foram fabricadas na Itália." ${ }^{9}$ Também a propósito de Buenos Aires, Pinedo (1928, p. 86) relata suas impressóes sobre os efeitos da viagem: "Nós fomos recebidos pelos notáveis da colônia, pelos dirigentes do fascio e da Sociedade Italiana. Houve um desfile das associaçôes italianas. $\mathrm{O}$ espetáculo da multidão foi emocionante [...] eles exaltaram-se ao constatar que o governo italiano náo os tinha esquecido.”

Por sua vez, na Itália, cidades-símbolos são escolhidas como centros de irradiação da 'cultura e do espírito latinos'; a exemplo de Gênova, em especial, lugar de partida última dos emigrados para as Américas. Prega-se que a inserção econômica e populacional da Itália na América do Sul teria passado por Gênova, sob a impulsão de seu centro industrial- financeiro e do desenvolvimento de seu porto. $\mathrm{O}$ discurso de Benito Mussolini pronunciado no 'Instituto Universitário de São Marino', em 24 de maio de 1926, é indicativo, “[...] esperamos que Gênova desempenhe um papel particular nas relaçóes culturais entre a Itália e os estados latino-americanos, lançando assim as bases de uma ação que pouco a pouco se concretizará." ${ }^{60}$ Proclama-se a redescoberta do verdadeiro destino dessa cidade, prognosticada a se tornar mais uma vez tão poderosa quanto fora no passado, a dar continuidade "à nobre e gloriosa tradição das antigas repúblicas italianas do Medievo". ${ }^{61} \mathrm{O}$ deputado Eugênio Broccardi afirma no editorial da revista Colombo,

[...] a proclamação da Grande Genova, significa sem dúvida que uma sólida vontade anima hoje todos os italianos. A esta cidade, que foi outrora grande sobre os mares, é devolvida 
seu esplendor primeiro, e isto por vontade de Mussolini. Nós estamos apenas no começo. Guiados pela sábia mão do Duce [...] Gênova reencontrará certamente o caminho da vitória. ${ }^{62}$

As instituiçôes superiores de Gênova são identificadas como órgãos essenciais para as abordagens culturais voltadas ao subcontinente latino. A Universidade de Gênova orienta-se, através da Faculdade de Letras, para os estudos de filologia moderna a fim de que seus estudantes pudessem seguir os movimentos literários e científicos das repúblicas latino-americanas. Professores universitários de Santiago, São Paulo, Buenos Aires, La Plata, Lima são convidados à Itália com vistas a ministrar cursos, bem como acadêmicos italianos são enviados ao subcontinente. Uma missão genovesa desembarca na Argentina, em fins de 1924, para melhor conhecer "[...] o jovem e ardente povo argentino e para sedimentar a primeira pedra do edifício que nós vamos construir juntos com os intercâmbios ulteriores de eruditos de todos os campos do saber."63

Gênova conta com um 'Instituto Italiano de Cultura Argentina', fundado para ser uma "resposta digna" ao 'Instituto Argentino de Cultura Italiana' e a "sua vasta biblioteca especializada." Esse último instituto, fundado no ano de 1923 em Buenos Aires, pretendia
“[...] cultivar as interaçóes culturais entre a Argentina e a Itália nos campos científicos, literários e artísticos, promovendo a vinda à Argentina de universitários e de renomadas per- sonalidades das artes e das letras, e obtendo que professores das Universidades e intelectuais argentinos fossem à Itália." ${ }^{64}$

De fato, os profissionais argentinos são os mais presentes em Gênova, como Arturo Rossi, chefe de uma missão chegada à cidade em 1927. Nessa ocasiáo, Rossi concede,

[...] o progresso da Argentina é devido, em grande parte, ao povo italiano, o qual foi pioneiro em civilità. Os italianos converteram em cidades e vilarejos as terras que antes eram os pampas desérticos. Identificam-se verdadeiros e apropriados vínculos 
de sangue que se evidenciam quando pensamos que mais da metade da população argentina é originária do solo italiano. ${ }^{65}$

Em Roma, por sua vez, pretendia-se instaurar a 'Casa de Colombo': "É sobre os auspícios de Roma e Gênova que o Istituto Cristoforo Colombo quer criar um centro onde os povos de língua espanhola e portuguesa possam encontrar um pequeno espaço de sua pátria" "66, anuncia a revista Colombo. A casa comportaria, graças às doaçóes dos países associados ao Instituto, uma biblioteca e uma sala de leitura, com revistas, jornais, publicaçóes oficiais e informaçôes as mais variadas sobre o mundo 'latino'. Previam-se salas de conferências, de reunióes e de concertos; exposiçóes permanentes de produtos dos países latino-americanos e de feiras de produtos italianos. ${ }^{67}$

\section{Consideraçóes finais}

Enfim, a despeito dos inegáveis esforços e açōes práticas do regime fascista em relação à América Latina, os resultados computados em fins dos anos vinte mostravam-se, segundo os dirigentes italianos, decepcionantes. Múltiplas seriam as explicaçôes. O que para a Itália aparecia como um empreendimento de monta diluía-se nesse vasto subcontinente, onde a superação da concorrência político-econômica e cultural de naçóes como Inglaterra, Estados Unidos, França e Alemanha revelava-se muito mais intransponível do que o imaginado pela Itália. As suas próprias comunidades emigradas não haviam dado resposta satisfatória aos apelos tardios da Madre Patria, em funçáo, dentre outros fatores, do grau adiantado de assimilação em que os mesmos se encontravam em muitos lugares, em especial, nas grandes cidades, como Buenos Aires e São Paulo. Na virada dos anos vinte, com a diminuição da emigração italiana para a América do Sul, a Itália viu seu interesse por essa parte do mundo diminuir consideravelmente. Nessa época, ela passa a privilegiar mais e mais sua influência crescente na Europa central e balcânica, onde julga possuir melhores condiçôes de manobra, bem como seu avanço em território africano, esperando que se efetue a conquista da Etiópia e a expansáo de 
sua vocação colonizadora. Os anos em que a América Latina aparecia como um horizonte importante e possível de sua política internacional haviam passado, em meio à ilusáo sobre as próprias capacidades materiais e operacionais da Itália em realizar um projeto de inserção de tal monta. Os anos marcaram esse afastamento progressivo, com momentâneas retomadas, como na ocasiáo da busca de apoio em países latino-americanos face à crise desencadeada na Sociedade das Nações, quando da invasáo italiana da Etiópia em 1935-1936. Logo, porém, a Itália fascista já imersa nos problemas europeus, rumou para o abismo e para seu fim com a Segunda Guerra Mundial.

\section{ITALIAN FASCISM IN LATIN AMERICA: BETWEEN ROMANITÀ AND LATINITÀ}

Abstract: The present article studies the international political course of Italy during the fascism, specifically the manifested interest that nation showed in Latin America in the 1920s, judged feasible at the moment of a broader approach in economical and political-cultural terms. The strategies for insertion passed through the political uses of the conception of latinidad, conceived as a communion factor between those people. With such legitimation bias, a series of initiatives were experimented by the Mussolini regime in the latin-american continent.

Keywords. Fascism. Latin America. Latinity. International Policy.

\section{Notas}

${ }^{1}$ Já em 1899, o ex-vice-cônsul italiano na Argentina, Gino Machioro (Il nostro avenire in America. In: Nuova Antologia, fasc.67, dez.1899. p. 528) mostrava certa lucidez das factíveis possibilidades da Itália no 'novo continente': "[...] nossa missão é de manter e, quando o caso se apresenta, de promover a entrada de nossas colônias na órbita dos interesses da Madre Patria. Mas, sem nenhuma ideia, mesmo que subentendida, de ambição política. Se nós quiséssemos praticar um imperialismo colonial na América, nós mostraríamos que nós não conhecemos nem a Itália, nem a América, e, sobretudo, ignoramos completamente nossa colônia." ${ }^{2}$ A imagem da Itália necessariamente deveria mudar na América Latina, de acordo com Corriere Italiano (n ${ }^{\circ} 34,24$ de agosto de 1924, p. 4) "[...] dado que no Brasil, na Argentina, no Uruguai, no Paraguai, no Chile, na Bolívia, no Peru, no Equador, no Panamá, na Colômbia, na Venezuela vivem milhares de italianos. Se, depois de 
quase um século, esses valorosos combatentes triunfaram graças ao seu extenuante trabalho e sua boa educação, eles, no entanto, jamais conseguiram destruir a fábula da Itália miserável e entregue aos marginais. A Itália permanece inexoravelmente a nação pobre que seus próprios cidadãos a abandonam para sempre."

${ }^{3}$ Sobre a temática, ver entre outros: BRANDALISE, Carla (2005); SCARZANELLA, Eugenia (2005); ALIANO, David (2012); BERTONHA, Fábio (2001); FINCHELSTEIN, Federico (2010).

${ }^{4}$ A rivalidade entre Itália e França, anterior à Segunda Guerra Mundial, aparece, por exemplo, no texto de Ettore Rota (1939).

${ }^{5}$ Entre as revistas, as mais destacadas foram: Rivista d'Italia e d'America (1923-28); Le Vie d'Italia e dell'America Latina (1924-32); Colombo (1926-31).

${ }^{6}$ Roma e la tradizione latina. In: Colombo, vol. I, junho, 1926, p. 6.

${ }^{7}$ Solidarietà italo-argentine. In: Colombo. v.I, junho 1926. p. 72.

${ }^{8}$ La nuova e la vecchia America. In: Rivista d'Italia e d'América, ano III, dez. 1925. p. 65.

${ }^{9}$ Para a progressiva construção do estado fascista intervencionista e corporativo, Ver: PALLA, 2001; MESSINA, 2013.

${ }^{10}$ Segundo Sánchez (1995, p. 137): "Esse aspecto das relaçóes entre os dois países [Espanha e Itália] é bastante desconhecido; entretanto, ele é muito importante; essas relaçóes se desenvolveram em torno dos interesses que o governo fascista mantinha essencialmente em matéria de política e economia na América hispânica." ${ }^{11}$ Prefazione. In: Annuario d'Italia et dell'America Latina. Roma: Istituto Cristoforo Colombo, 1930. p. 03

${ }^{12}$ Collaborazione Italo-spagnola nell'America Latina. In: Le Vie de l'Italia et dell'America Latina, no 10, out. 1926. p. 1215

${ }^{13} \mathrm{O}$ italiano Luigi Bacci, professor de espanhol, era um defensor, desde a época liberal, das vantagens da aproximação entre países latinos, convencido que estava sobre o fato de que as nações latinas deveriam recuperar, nas relações internacionais, o grande papel do Império romano, em contraposição à ascensão do mundo anglo-saxão. Durante sua participação no Instituto, procurou mantê-lo com um forte caráter cultural, com base em trocas intelectuais e de conhecimento mútuo entre os países envolvidos, ao planejar toda gama de interações nesse sentido. (MÉNDEZ, 2013b). Ver as reflexóes posteriores de Luigi BACCI (1932).

${ }^{14}$ BACCI, Luigi. Lattività dell'Istituto Cristoforo Colombo. In: Colombo, fasc.V, set. 1927. p. 223. A ambição de criar o Istituto se manifestara na Itália antes mesmo do golpe de estado do general Rivera, mas o último governo constitucional espanhol não respondera à proposição com grande entusiasmo. E isso basicamente por duas razóes: em primeiro lugar, os espanhóis haviam constatado que, em enquete prévia efetuada nos países latino-americanos, esses últimos não demonstraram grande interesse pela iniciativa italiana; em segundo lugar, o governo espanhol 
manifestara estranheza e insatisfação ao fato do projeto excluir a França, a qual nessas condiçôes seria o único país 'latino' sem representação. Como exemplo das dificuldades preliminares, sublinhavam os espanhóis, a Argentina havia declarado preferir manter seus vínculos privilegiados somente com a Itália, sem partilhá-los com outras naçóes concorrentes do continente americano. Da mesma forma, o governo argentino se posicionara contra o ostracismo da França. A posição da Espanha mudará com o advento de Rivera na estrutura governamental. Ao proclamar encerrado o governo parlamentar espanhol, no mês de setembro de 1923, Rivera instaura, com o apoio do rei Afonso XIII e dos militares, um regime de exceção, propício às relações governamentais com Mussolini. (LERMA, 1989, p. 269-278, grifos nossos)

${ }^{15}$ Colombo. fasc.I, junho, 1926. p. 1.

${ }^{16}$ Attraverso i paesi iberici del vecchio e nuovo mondo: suplemento economico mensile di Colombo. Roma: Istituto Cristoforo Colombo, 1928.

${ }^{17}$ Colombo, fasc. I, junho 1926. p. 1.

${ }^{18}$ Colombo, fasc.II, agosto 1926. p. 159.

${ }^{19} \mathrm{~A}$ coleção de obras referentes a essa temática publicada pelo Istituto na década de 1920 compreendia, entre outras: BLAIS, Valeria. Nicaragua; BORGHI, Giulio. Colombia; GALLEGARI, G.V. Messico; CUMIN, Gustavo. Il Perù; LANTINI, Pietro. Guatemala; MORI, Mario. San Domingo; MORINI, Armando. Venezuela; NINNI, Alessandro. Chile; QUARTA, Oronzo. Costa Rica; RICCARDI, Ricardo. Equador. Ver: Colombo. fasc. V, set. 1927. p. 256-257.

${ }^{20}$ Nos sumários da revista Colombo encontra-se, por exemplo: FARINELLI, Arturo. Ritorno a Figaro, p. 14-18; e ORLANDO, Vitorio Emanuele. Sulla Constituzion argentina, p. 8; GIURIATI, Giovani. Tradizioni d'italianità nell'America latina, p.4-5. In: Colombo, fasc.I, junho 1926.

${ }^{21}$ GIANNINI, Amadeo. Proemio. In: Colombo, fasc.I, junho 1926. p. 1-2, grifos nossos.

${ }_{22}$ MUSSOLINI, Benedito. Messaggio. In. Colombo. fasc. I, junho 1926. p. 3. Em homenagem, um pré-fascículo de Colombo fora lançado em 21 de abril de 1926, o 'Natal de Roma', data sagrada de "todos os povos latinos"

23 "Em junho de 1921, o infante D. Ferdinando, líder de uma missão que o rei da Espanha lhe havia confiado, cujo objetivo definido era uma reaproximação entre a Espanha e seus filhos do além-mar, voltava de uma viagem, considerada frutuosa, na América do Sul." Il resoconto del viaggio in America dell'Infante D.Fernando: i suoi messagi a nome del Re di Spagna. In: Almanaque Ilustrado Hispano-americano, 1922. p. 3.

${ }^{24}$ AMADASI, A. La crociera di S.A.R. il principe ereditario nell'America Latina. In: Le Vie d'Italia e dell'America Latina, n' 3, março 1925. p. 263.

${ }^{25}$ Id. Ib., p. 264, grifos nossos. 
${ }^{26}$ Id. Ib., p. 269. Em 1924, o Brasil viva a 'Revolta paulista de 1924', liderada pelo general Isidoro Dias Lopes, constituiu uma segunda fase do movimento tenentista de 1922. A intenção era destituir o Presidente da República, Artur Bernardes. $\mathrm{Na}$ reação, a capital paulista sofreu um bombardeamento aéreo. Cohen (2006). ${ }^{27}$ Plus Ultra: S.A.R. Umberto di Savoia - principe di Piemonte nell'America Latina. Buenos Aires, set. 1924. p. 01. O jornal argentino, La Prensa, aproveita a ocasiáo para publicar um caderno, em 06 de agosto de 1924, a propósito da "obra dos italianos na Argentina”, com os seguintes artigos: La inmigración italiana en la República Argentina; La influencia italiana en la cultura argentina; La actuación de ingenieros y arquitectos italianos en la Argentina; La influencia artística de Italia en la república Argentina; Los músicos italianos en la República Argentina: síntesis de su labor; La contribución italiana al desenvolvimiento intelectual de la Republica; El teatro italiano in Buenos Ayres a través de medio siglo.

${ }^{28}$ Citado por Le Vie d'Italia e dell'America Latina, n' 9, set.1925, p.1109.

${ }^{29}$ Como produção mais recente sobre a Nave Italia, ver também: VERNASSA, Maurizio (1999); TRENTO, (2008).

30 "Crociera Italiana nell'America Latina. Ordine del giorno approvato nel Convegno tenutosi a Roma il 30 gennaio 1923 sotto la presidenza di S. Rossi Ministro per l'Industria e Commercio", p. 05. ASMAE: "Fondo Giuriati" (Archivio della Camera dei Deputati- Roma).

${ }^{31}$ La grande fiera campionaria navigante nell'America Latina. In: Le Vie d'Italia e dell'America Latina, n. 3, março 1924, p.383.

${ }^{32}$ Giovanni Giurati, responsável maior pela missão, era um homem de Estado, de orientação nacionalista, que se interessava fortemente pelos assuntos relacionados à emigração. Fundara em 1920, junto com Oscar Sinigaglia, a 'Liga italiana pela tutela dos interesses nacionais no exterior', entidade que substituiu a organização 'Trento e Trieste', da qual ele havia sido presidente. À 'Liga' haviam aderido políticos, intelectuais, empresários, todos se propondo a fomentar propagandas culturais e econômicas nos países estrangeiros comportando uma imigração italiana. Entre as sedes da Liga fundadas no exterior, a de Buenos Aires fora fundada em janeiro de 1923. A Liga foi dissolvida neste mesmo ano de 1923 por Mussolini, que pretendia a fusionar com a nova organização dos Fasci italiani all'estero. Fabiano (1985). ${ }^{33}$ GIURIATI, Giovanni. Tradizioni di italianità nell'America latina. In: Colombo, fasc. I, juin 1926. p. 4.

${ }^{34} \mathrm{O}$ artista participou da decoração interna da Nave Italia, esteve presente na seleção de obras artísticas embarcadas, ao mesmo tempo que produziu inúmeros aquarelas a bordo. Sobre a atuação de Sartorio no circuito marítimo, ver: Aristide Sartorio 1924. In: MANTURA; PAINO; OSIO (1999).

${ }^{35}$ La grande fiera campionaria navigante nell'America Latina. In: Le Vie d'Italia e dell'America Latina, $\mathrm{n}^{\circ}$ 3, março 1924, p. 384. 
${ }^{36}$ Ver: Camera Italiana di Comercio ed Arti di San Paolo del Brasile. Relazione presentata alla Crociera della R.Nave 'Italia'. São Paulo: Rossetti \& Rocco,1924. ${ }^{37}$ Por ocasião da chegada da Nave Italia no Chile, a Câmara de Comércio Italiana de Valparaíso publica Il Cile e gli Italiani del Cile a fim de "cooperar, em especial entre os italianos, para um mais exato conhecimento de nosso país hospedeiro, o Chile, pois os italianos aqui residentes souberam ao longo de anos de esforços e trabalho, adquirir forças moral e econômica." BRACCHIGLIONE, Ettore; CARMINATI, Aldo (Ed.). Il Cile e gli Italiani del Cile: omaggio alla crociera italiana nell'América Latina.Valparaiso: Camera Italiana di Commercio, junho 1924, p. 01. ${ }^{38}$ Id. Ib., p. 02.

${ }^{39}$ Le Vie d'Italia e dell'America Latina, n. 7, julho, 1925. p. 882; Colombo, fasc.V, set. 1927. p. 256. Ver também, entre outros: CARRARA (1925); MISEROCCHI (1925); ROCCA (1926).

${ }^{40}$ Os Estados Unidos eram acusados, pela revista Colombo, de querer instrumentalizar o pan-americanismo, "[...] esse país quer tirar proveito do conhecido movimento pan-americano, o qual, na verdade, tem um só objetivo imediato: a proteção dos interesses econômicos e políticos dos Estados Unidos. O princípio 'América aos americanos' se tinge de uma cor yankee que mal disfarça as reais intençóes, caminhando junto com o sistema bancário e comercial, onde a estratégia é uma só e náo deve ser esquecida: o continente americano - a totalidade!!! - deve ser subtraída da influência europeia (leia-se latina). Per la difesa della nostra cultura e economia nell'America Latina. In: Colombo, fasc.XVIII, maio-junho, 1929. p. 231. ${ }^{41}$ Id.Ib.,p. 231.

${ }^{42}$ Id.Ib., p. 231.

${ }^{43}$ Para uma ideia da produção de revistas votadas à América Latina, por exemplo, ver: CHEYMOL (1988).

${ }^{44}$ L'Associazione Parigi e America Latina. In: Colombo, fasc. II, agosto, 1926. p. 167 , grifos nossos.

${ }^{45}$ Ver: Bulletin provisoire du Bureau d'études et de propagande: $\mathrm{n}$ 1-[2]. Association "Paris-Amérique latine", 1925

${ }^{46}$ La Revue de L'Amérique latine. n. 11. nov. 1926. p. 67. Esse periódico francês circulou, de maneira náo regular nos anos finais, entre janeiro de 1922 a dezembro de 1932, com direçáo inicial Ernest Martinenche, originou-se do Bulletin de l'Amérique latine, que fora uma criação do Groupement des Universités et Grandes Écoles de France pour les relations avec l'Amérique latine. Segundo Charles LESCA (s.d., p. 428), um dos redatores-chefes da revista, na Action du groupement pendant les années 1921 et 1922, Martinenche expusera a concepção da revista: "mais livre e mais ampla que uma revista universitária, dando uma ideia precisa de todas as manifestaçóes espirituais da América Latina, apresentado 
ao mesmo tempo a nossos amigos do Novo Mundo um quadro sincero e variado do movimento intelectual e artístico da França."

${ }^{47}$ Colombo, dez., 1926, p. 22. Entre os mais graves pontos de fricção entre França e Itália, estava o fato de a nação francesa se tornar o maior centro de exílio dos antifascistas italianos, os fuoruciti, que já começara nos anos de 1920-1921, antes mesmo da chegada de Mussolini ao poder e se intensifica de acordo com as ondas de repressão política italiana. (GROPPO, 1996, p. 30-33).

${ }^{48}$ Colombo, fasc.I, junho, 1926, p. 91. Manuel Ugarte (1910, p.201) já havia declarado que a "América meridional tinha se entregado à França com a ingenuidade de uma virgem." (grifos nossos).

${ }^{49}$ Grazia Dore (1964, p. 156-157) mostra a recorrência dessa impressão por parte da Itália: "Nós encontrávamos [...] preciosos ensinamentos no exemplo alemão que, sem ter colônias, nem possessóes próprias, praticava uma ativa troca de matérias primas e produtos fabricados com os países transoceânicos [...] casas alemãs se multiplicavam nesses centros colônias. Regióes inteiras se dedicavam à uma indústria que não teria existido de uma outra forma."

${ }^{50}$ Ver: Germania e le Americhe del Sud. In: Rivista Coloniale, anno X, n. 9, Roma, 30 sept. 1915. p. 10.

${ }^{51}$ Apud BLANCPAIN (1994, p. 267). Ou ainda, o relato mais agressivo do pangermanista W.Wiltzer, escrito em 1900, "Será preciso um Anschluss dos alemães da América Latina apoiados pela frota alemã: começaremos com a proteção dos alemães da Venezuela contra as inequidades e as perpétuas convulsóes políticas. Quem acredita na missão mundial dos alemães, quem compara a raça alemá no estrangeiro com as outras raças que com ela convivem se persuade amplamente das nossas ambiçóes bem fundamentadas e se sente inspirado a trabalhar em prol de uma expansão sistemática." Apud id.ib., p. 268.

${ }^{52}$ Segundo Pierre Milza e Serge Berstein (1980, p. 202): Para sua política estrangeira e sua propaganda fora da Itália, o regime tinha necessidade de homens diferentes daqueles que podiam oferecer os quadros tradicionais [...] Assim, o governo nomeou, a partir de 1926, um grande número de cônsules fascistas. Em janeiro de 1928 [...] quase todos os postos no estrangeiro estavam em mãos de funcionários devotados ao regime."

${ }^{53}$ La cerimonia inaugurale del cavo sottomarino fra l'Italia e l'America della Italcable. Milano: Modiano, 1926, p. 4.

${ }^{44}$ Il Cavo tra l'America e l'Italia. In: Rivista d'Italia e d'America, n. 15, março 1925, p.71-72.

${ }^{55}$ Id.Ib.

${ }^{56}$ Un cavo italiano con l'America Latina. In: Le Vie d'Italia e dell'America Latina, n. 2, fev. 1925, p. 237.

${ }^{57}$ Le Vie d'Italia e dell'America Latina, n. 4, abril 1925. p. 391 e Le Vie d'Italia e dell'America Latina, n. 12, dez. 1925.

Anos 90, Porto Alegre, v. 23, n. 43, p. 199-233, jul. 2016 
${ }^{58}$ Le Vie d'Italia e dell'America Latina, n. 4, abril 1925, p. 391 (grifos nossos)

${ }^{59}$ Apud Il trionfale volo di De Pinedo sulle acque e le terre dell'America Latina. In: Le Vie d'Italie e dell'America Latina, n 5, maio 1927. p. 507 (grifos nossos). ${ }^{60}$ Citado pela revista Le Vie d'Italie e dell'America Latina, n. 2, fev. 1927. p. 248. ${ }^{61}$ BROCCARDI, Eugenio. Nelle terre di America. In: Colombo, fasc., junho 1926. p. 7

${ }^{62}$ Id.Ibid. p. 7.

${ }^{63}$ Genova e le relazioni culturali con l'America Latina. In: Corriere Italiano, n45, nov. 1924. p. 2

${ }^{64}$ Gli scambi culturali fra i centri universitari d'Italia e del Sud-america. In: Le vie d'Italia e dell'America Latina, $1^{\circ}$ jan. 1925. p.53.

${ }^{65}$ Professori argentini a Genova. In: Le vie d'Italia e dell'America Latina, n4, abril 1927. p. 486 (grifos nossos).

${ }^{66}$ L'avvicinamento Italo-argentino : l'opera dell'Istituto 'Cristoforo Colombo'. In: Colombo, fasc. II, março 1927. p. 38.

${ }^{67}$ BACCI, Luigi. La Casa di Cristoforo Colombo. In: Colombo, fasc.V, set.1927. p. 260 - 261(grifos nossos).

\section{Referências}

ALIANO, David. Mussolini's National Project in Argentina. Madison: Fairleigh Dickinson University Press, 2012.

BACCI, Luigi. Estirpe latina: libro de lectura. Roma: Società Editrici Dante Alighieri, 1932.

BERSTEIN, Serge; MILZA, Pierre. Les fascisme italien: 1919-1945. Paris: Seul, 1980.

BERTONHA, Fábio. O fascismo e os imigrantes italianos no Brasil. Porto Alegre: Edipurcs, 2001.

BIANCO, Francesco. L'Italia e il Brasile: la lotta dei giganti nell'America del Sud e la fortuna del mercato italiano. Milano: Fratelli Treves, 1920.

BIDWELL, P.W. Latin America, Germany and the Hull Program. In: Foreign Affairs, v.17, n. 2, jan. 1939. p. 374-390.

BLANCPAIN, Jean-Pierre. Migrations et mémoire germaniques en Amérique latine. Presses Universitaires de Strasbourg, 1994. 
BRACCHIGLIONE, Ettore; CARMINATI, Aldo (Ed.). Il Cile e gli Italiani del Cile: omaggio alla crociera italiana nell'América Latina.Valparaiso: Camera Italiana di Commercio, junho, 1924.

BRANDALISE, Carla. Les rapports internationaux de l'Italie envers l'Amérique latine: 1922-1936. Lille: ANRT, 2005.

CARATTI, Giuseppe. I rapporti Italo-argentino dopo la guerre. Acqui: Tipografia Pietro Righetti, 1917.

1926.

CARRARA, Enrico. Ventotto porti dell'America latina tra Atlantico e pacifico com a Regia Nave Italia. Torino; Giani, 1925.

CARRARA, Enrico. Ventotto porti dell'America latina tra Atlantico e pacifico com a Regia Nave Italia. Torino; Giani, 1925; MISEROCCHI, Manlio. L'America Latina attraverso il mio oblò. Pistoia: Grazzini, 1925; ROCCA, Enrico. Avventura sudamericana. Milão: Alpes, 1926.

CHEYMOL, Marc. Les revues latino-américaines à Paris (1900-1940), RdR, ${ }^{\circ}$ 5, 1988. p. 16-28.

CHOUTEAU. E. La France au Chili. Santiago, 1903.

COHEN, Ilka Stern. Bombas sobre São Paulo. A Revolução de 1924. São Paulo: Unesp, 2006.

CORRADINI, Enrico. L'emigrazione italiana nel Sud America. In: Nazionalismo italiano. Milano: Treves, 1914.

CUSANO, Alfredo. Il commercio con l'Italia e la navigazione direta. In: Il paese dell'avvenire. Rio Grande del Sud. Roma-Buenos Aires-São Paulo: L'ItaloSudamerica, 1920.

DE PINEDO, Francesco. Il moi volo attraverso l'Atlantico et le Americhe. Buenos Aires: El Bibliófilo Viau y Zona,1928.

DORE, Grazia. La Democrazia Italiana e l'emigrazione in America. Brescia: Morcelliana, 1964.

EINAUDI, Luigi. Il principe mercante. Studio sulla espansione coloniale italiana. Torino: Fratelli Bocca, 1890.

FABIANO, Domenico. La Lega Italiana per la tutela degli interessi nazionali e le origini dei Fasci italiani all'estero. In: Storia contemporanea, abril 1985.

FINCHELSTEIN, Federico. Fascismo trasatlántico: ideología, violencia y sacralidad en Argentina y en Italia, 1919-1945. Fondo de Cultura Económica, 2010. 
FRANZONI, Ausonio. Appunti sul programma della Sezione B del IV Congresso Geografico Italiano. In: L’Esplorazione commerciale, a.XVI, fasc.III, 15 fev. 1901. GENTILE, Emilio. L'emigrazione italiana in Argentina nella politica di espansione del nazionalismo e del fascismo. In: Storia Contemporanea, a. XVII, n .3, junho 1986.

GIURIATI, Giovanni. La Crociera Italiana nell'America Latina. Relazione di S. E. Giovanni Giuriati dinnanzi a S. M. il Re. Roma: Istituto Coloniale, 1925. GROPPO, Bruno. Exilés et réfugiés politiques dans la France du XXe siècle. Matériaux pour l'histoire de notre temps, v. 44, n. 44, 1996. P. 27-35.

GROSSI, Vincenzo. Storia della colonizzazione europea al Brasile e della emigrazione italiana nello stato di San Paolo. Milano-Roma-Napoli: Dante Alighieri, 1914 [1905].

INCISA, Luigi. Nel paese della fazenda. Milano: Felice Balzaretti,1926.

LERMA, Gustavo Palomares. Mussolini y Primo de Rivera. Política Exterior de dos dictadores. Madrid: Eudema, 1989.

LESCA, Charles. Histoire d'une revue. In: Hommage à Ernest Martinenche. Études hispaniques et américaines. Éditions d'Artrey, s.d.

LLI, Pietro. Al di là dei mari, Firenze: Vallecchi, 1925.

MACOLA, Ferrucio. L'Europa alla conquista dell'America Latina. Venezia: Ferdinando Ongania ed., 1894.

. Problemi e mezzi della nostra penetrazione economica nell'America Latina. Santiago, 1924.

MANCINI, Tommaso. Propaganda culturale ed espansione economica nell'America Latina. In: Problemi e mezzi della nostra penetrazione economica nell'America Latina. Santiago do Chile, 1924.

MANTURA, Bruno; PAINO, Maria Paula; OSIO, Bernardino (Org.). Aristide Sartorio 1924. Crociera della regia Nave "Italia" nell'America Latina. Roma: Istituto Italo-Latino Americano, 1999.

MAROCCO, Gianni. Sull'altra sponda del Prata: gli italiani in Uruguay. Milano: Franco Angeli, 1986.

MÉNDEZ, Rubén Domínguez. Francia en el horizonte. La política de aproximación italiana a la España de Primo de Rivera a través del campo cultural. Memoria y Civilización, v.16, 2013a, p.237-265. 
MÉNDEZ, Rubén Domínguez. Luigi Bacci, un actor de las relaciones culturales entre italia y españa a principios del siglo xx. Ogigia-revista electrónica de estudios hispánicos; no 13 (año 2013-b). p. 65-77.

MESSINA, Antonio. Lo Stato Etico Corporativo. Booksprint Edizione, 2013.

MILZA, Pierre. Les Fascismes. Paris: Seuil, 1991.

MISEROCCHI, Manlio. L'America Latina attraverso il mio oblò. Pistoia: Grazzini, 1925.

MUGNAINI, Marco. L'Italia e l'America latina (1930-1936): alcuni aspetti della politica estera fascista. In: Storia Contemporanea, n. 2, 1986. p. 199-244.

PALLA, Marco (Org.). Lo Stato fascista. Milano: La Nuova Italia, 2001.

PALOMARES LERMA, Gustavo. Mussolini y Primo de Rivera. Política Exterior de los dictadores, Madrid: Eudema, 1989.

PETITJEAN, Armand. La concurrence internationale et les sympathies françaises en Amérique latine. Paris: Imprimerie nationale, 1918.

PLUS ULTRA: S.A.R. Umberto di Savoia - principe di Piemonte nell'America Latina. Buenos Aires, set. 1924.

RANGONI, Domenico. Dopo un viaggio in Italia: contributo allo studio sulle relazione tra l'Italia ed il Brasile. São Paulo: Duprat \& Comp., 1903.

ROCCA, Enrico. Avventura sudamericana. Milão: Alpes, 1926.

ROTA, Ettore. Italia e Francia davanti alla storia: il mito della sorella latina. Milano: Istituto per Studi di Politica Internazionale, 1939.

SÁNCHEZ, Victoriano Peña. Intelectuales y Fascismo: la cultura italiana del Ventennio fascista y su repercusión em España. Granada: Universidad de Granada, 1995.

SCARZANELLA, Eugenia (Org.). Fascisti in Sud America. Firenze: Le Lettere, 2005.

TANNENBERG O.R. La plus Grande Allemagne: l'œuvre du 20ème siècle. Lausanne: Payot, 1916.

TRENTO, Angelo. I viaggiatori italiani in America Latina in era fascista tra curiosità e ideologia. In: MORICOLA, Giuseppe (Org.). Il viaggio degli italiani in America Latina tra Ottocento e Novecento. Napoli: Guida, 2008.

UGARTE, Manuel. El porvenir de la America latina: la raza, la integridad territorial y moral, la organisatión interior. Valencia: F. Sempere, 1910. 


\section{Carla Brandalise}

UGOLOTTI, Filippo. Italia e Italiani in Brasile: note e appunti. São Paulo: Riedel e Lemmi, 1897.

VERNASSA, Maurizio. Una crociera di propaganda. In: Politica Internazionale. 1-2, 1999. p. 213-221.

VILLA, Oreste. L'America latina problema fascista. Roma: Nuova Europa, Stampa, 1933.

Recebido em: 12/ 12/ 2015

Aprovado em: 19/ 03/ 2016 